\title{
Jihadisme Salafi versus pemikiran mubaligh dan guru agama
}

\author{
Muh Saerozi
}

STAIN Salatiga dan Univesitas SultanAgungSemarang

E-mail: saerri2010@yahoocm

Judul Buku : NII sampai JI Salafy Jihadisme di Indonesia

Penuis : Solahudin

Pengantar : Greg Fealy

Penerbit : Komunitas Bambu

Cetakan : Mei 2011

Tebal : xviii $+294 \mathrm{hlm}$.

K untowijoyo menerbitkan buku Matoddog sgarah edisi pertama tahun 1994 dan edisi kedua tahun 2003. Buku Kuntowijoyo edisi kedua itu memuat bab khusus tentang sejarah pemikiran. Perbedaan isi buku tersebut bukan hanya memberi kesan bahwa sejarah pemikiran merupakan bagian penting dari pemikiran Kuntowijoyo, tetapi juga memberi pesan bahwa sejarah pemikiran merupakan pengetahuan yang penting dalam studi sejarah.

K untowijoyo secara tegas menulis "Semua perbuatan manusia dipengaruhi pemikiran... Karenanya, sebagai 'daging yang berpikir', manusia tidak bisa lepas dari dunia pemikiran" (Kuntowijoyo, 2003:189). Penegasan Kuntowijoyo tersebut sangat dekat dengan cara berfikir Solahudin dalam buku ini. Solahudin berhasil menjelaskan betapa pemikiran teologis telah mempengaruhi gerakan-gerakan sosial, seperti terjadi pada diri para eksponen D arul Islam (DI) dan Salafi Jihady. Pemikiran teologis itu tidak mesti lahir secara oroginal dari diri pelaku, tetapi bisa muncul secara genealogis dari tokoh-tokoh generasi sebelumnya. 
Kebetulan atau sengaja, ada refleksi metodologis Kuntowijoyo yang tercermin dalam buku Solahudin (2011). Misalnya, model gensisdalam "kajian teks" K untowijoyo terrefleksi pada upaya Solahudin menelusuri asal-usul gerakan dan paham Salafi Jihadisme di Indoensia (Solahidun, 2011: 1, 8). Model "kajian konteks sejarah" terefleksi pada upaya Solahudin menjelaskan kausalitas sosial yang terjadi di Timur tengah dan Indonesia tahun 1940 sampai dengan tahun 2002 (Solahudin, 2011: xii). Begitu pula model "implementasi" terefleksi pada upaya Solahudin menjelaskan tentang kerja keras para eksponen Negara Islam Indonesia (NII) dan Jamaah Islamiyah (JI) dalam menegakkan konsep tauhidnya (Solahudin, 2011: 7, 115).

Sebagai seorang warga negara Pancasila, Solahudin buru-buru mengambil jarak yang tegas dengan pemikiran orang-orang yang ditulisnya. Misalnya, ia menyebut aksi bom Bali O ktober 2002 sebagai “aksi keji” (Solahudin, 2011: 8). Di sisi lain, Solahudin sebagai seorang peneliti berusaha obyektif dan hati-hati menjaga etika akademis. Usaha berpikir obyektif dan hati-hati itu tampak, misalnya, dalam membandingkan persamaan dan perbedaan citacita Muhamamdiyah dan D I pada era 1950-an. Disebutkan bahwa Muhammadiyah meskipun pernah memiliki persamaan cita-cita politik dengan DI, yaitu menegakkkan syari'at Islam, tetapi Muhammadiyah lebih memilih jalur Parlementer sehingga eksis sampai sekarang. Sedangkan DI memilih jalur ekstra parlementer akhirnya berujung pada pemberontakan dan nasib penumpasan seperti terjadi pada Kartosuwiryo (Solahudin, 2003:4, 77).

Sumber data yang digunakan Solahudin untuk merekontruksi sejarah juga akurat. Interpretasi ditarik secara hati-hati dari fakta-fakta yang renik tanpa mengabaikan misi untuk memudahkan pembaca mahami isi buku secara detail. Misalnya, penyebutan tentang proses diskusi yang terjadi dalam rapat-rapat, penyebutan nama-nama peserta rapat, penyebutan nama-nama tempat, dan penulisan alur peristiwa-peristiwa secara runtut.

Solahudin selaku penulis buku ini juga kelihatan sangat menghayati pergulatan madzhab "bebas nilai" (valuefre) melawan mazhab "sarat nilai" (valuebound). Namun, ia tetap berpihak pada madzahab yang "sarat nilai". O leh karena itu di akhir buku, ia secara turut befatwa kepada pembaca supaya menjauh dari pemikiran irhabiah dengan mengutip pernyataan terpidanan mati Ali Imron. 
Jihad di jalan Allah yang seharusnya menjadi pelindung Islam dan kaum muslimin, justru menjadi penyebab terganggunya kaum muslimin. Jihad di jalan Allah yang seharusnya menjanjikan kejayaan, justru menjadi penyebab para pelaku pengeboman, dan yang terlibat membantu para pelaku pengeboman terhina karena mereka harus dicari, dikejar, dan dipenjarakan. Dan jihad di jalan Allah yang seharusnya menjadi sarana untuk menghilangkan fitnah, justru malah menyebabkan timbulnya fitnah. Semua itu disebabkan karena salah dalam menjalankan dan menerapkan kewajiban jihad di jalan Allah (Solahudin, 2011:268).

D i sinilah signifikansi sejarah yang dikemukakan oleh K untowijoyo (2001: 20-31) tampak semakin jelas dalam buku ini. Sejarah bukan hanya memiliki signifikansi intrinsik untuk mengetahui masa lampau, tetapi juga memiliki sigifikansi ekstrinsik seperti, sebagai pendidikan moral, pendidikan penalaran, pendidikan politik, pendidikan kebijakan, pendidikan perubahan, dan pendidikan masa depan. Andai Kuntowijoyo membaca buku ini, kemungkinan besar ia akan mengapresiasi sebagai salah satu contoh dalam buku mtoddog sjarah seperti pernah dilakukannya pada tulisan Achmadi (Kuntowijoyo, 2003:198).

\section{Pekerja rumah untuk guru agama}

Harun Nasution (1986: ix) menjelaskan bahwa setiap orang yang ingin mendalami seluk beluk agama perlu mempelajari teologinya. Pemahaman teologi yang mendalam akan membawa seseorang pada keyakinan berdasarkan pada landasan yang kuat sepanjang masa. Teologi dalam istilah Arab disebut juga ilmu ushuluddin yang berarti ilmu tentang pokokpokok agama atau Ilmu Tauhid. K ata tauhidmengandung arti satu atau esa. Keesaan dalam perspektif Islam sebagai agama monothesisme merupakan sifat yang terpenting di antara semua sifat Tuhan.

Gerakan Salafi memiliki konsep pemikiran tauhid sendiri. Begitu pula gerakan Salafi Jihady dan D I. Eksponen D I menyusun konsep tauhid yang dikawinkan dengan pemikiran Abu A'la Al-Maududi dan Sayid Qutb. Dari situ lahir konsep Tauhid Rububiyah, Tauhid Mulkiyah, dan Tauhid Uluhiyah (RMU). Eksponen Salafy menyusun konsep Tauhid Uluhiyah, Tauhid Rububiyah, dan Tauhid Asma dan sifat. Eksponen Salafi Jihady menyusun konsep Tauhid Rububiyah, Tauhid Uluhiyah, tauhid Asma dan sifat, dan Tauhid Hakimiyah. Konsep tauhid dari tiga kelompok tersebut berbeda secara metodologis. Namun seiring dengan perjalanan sejarah, konsep tauhid versi DI akhimya semakin mirip dengan doktrin Tauhid Hakimiyah versi Salafi Jihady (Solahudin, 2011: 273). Inti dari Tauhid Hakimiyah 
adalah "pandangan bahwa kedaulatan politik sepenuhnya milik Allah" (Solahudin, 2011: 28). Konsep ini bertentangan dengan konsep kedaulatan menurut logika demokrasi. Sebagaimana diketahui bahwa demokrasi menempatkan kedaulatan rakyat sebagai kedaulatan politik tertinggi.

Konsep TauhidHakimiahmemiliki implikasi normatif dan empirik. Implikasi normatif muncul dalam bentuk pengkafiran atau pemurtadan terhadap orang yang tidak taat terhadap konsep tersebut. Penguasa yang menolah konsep Tauhid Hakimijah sama halnya dengan menolak syari'at Islam dan Hakimiyah Allah Bila mereka yang menolak tadi mengaku muslim, berarti telah murtad. Memerangi penguasa murtad, menurutFaraj, hukumnya fardlu 'ain (Solahudin, 2011:28-29).

Konsep Tauhid Hakimiyah atau Tauhid Mulkiyah meskipun sudah lahir sejak lama, tetapi tidak pernah diajarkan di madrasah dan sekolah di Indonesia. Istilah tersebut bahkan tergolong asing di sekolah atau madrasah. Sekolah pada umumnya hanya mengajarkan Tauhid Uluhiyah dan Tauhid Rububiyah. Konsep Tauhid Uluhiyah mengaktualisasikan potensi siswa untuk meyakini bahwa Allah sebagai Tuhan Yang Maha Esa dalam sifat, dzat, dan af'al-Nya. Konsep Tauhid Rububiyah mengaktualisasikan potensi siswa untuk meyakini bahwa Allah adalah satu-satunya pengatur dan pemelihara seluruh alam ciptaan-Nya.

Buku Solahudin ini memberi informasi historis kepada para guru untuk mengetahui Tauhid Hakimiyah dan Tauhid Mulkiyah Bagi kebanyakan guru Pendidikan Agama Islam (PAI) tentu mereka sulit menjawab bila ditanya tentang maksud konsep Tauhid Mulkiyah atau Tauhid Hakimiyah. Mereka yang mengajar di SD sampai perguruan tinggi tentu asing dengan konsep kedua istilah tauhid itu. Mereka bisa jadi juga sulit menjawab ketika ditanya alasan mengajarkan tauhid yang hanya Rubjliyahdan Uluhiyah

Biasa berlaku, sesuatu yang baru akan menarik perhatian para guru. Begitu pula informasiinformasi baru tentang ilmu tauhid yang selama ini terpendam dalam sejarah D I. Ada dilema politis dan akademis untuk menyampaikan konsep pemikiran yang masih dianggap tabu. Namun seperti kata peribahasa; nasi sudah menjadi bubur. Solahudin telah membuka tutup kotak pandora konsep ketauhidan D I dan Salafi Jihady secara panjang lebar dalam buku ini. Penyebaran buku ini tentu terjangkau pula oleh para guru yang rajin membaca. 
Sekarang tinggal ada beberapa tawaran kepada guru PAI. Tawaran petama, mereka dibiarkan mengenal pemikiran-pemikiran salafi jihadisme tanpa bimbingan atau mereka dikenalkan dengan bimbingan. Keelua, mereka dikenalkan pada pemikiran salafi jihadisme dengan pendekatan tektual atau mereka dikenalkan dengan pendekatan kontekstual.

Tawaran-tawaran pendekatan kontekstual atau tekstual kepada guru itu memiliki implikasi. Tindakan untuk melarang buku Solahudin jelas tidak mungkin, sebab sudah tidak zamannya melarang guru untuk memperoleh informasi yang akademis aktual. Bila pengenalan konsep dilakukan kepada guru hanya dengan pendekatan tekstual, mereka sangat mungkin akan bersikap apologis untuk menolak atau justru menerimanya. Bila pengenalan konsep dilakukan kepada mereka dengan pendekatan kontekstual, mereka tentu akan memiliki sikap kritis untuk menolak, menerima, atau melakukan modifikasi.

Pendekatan histroris kontekstual untuk menjelaskan paham keagamaan yang mirip jihadisme salafi pernah dilakukan oleh Harun Nasution (1986: 6-7). Paham keagamaan yang dimaksud adalah adalah khawarij pada zaman sahabat Ali bin Abi Thalib. Harun Nasution mengawali penjelasan kontekstualnya dengan menyampaikan semboyan Khawarij yang berbunyi lahukmaillaAllah (tidak ada hukum selain dari hukum Allah). D engan semboyan ini, kaum khawarij menganggap kafir terhadap orang-orang yang bersebarangan secara politis dengannya. Mereka yang dianggap kafir adalah para sahabat Nabi seperti Ali bin Abi Thalib, Muawiyah, dan Amr bin A sh. Ali bin Abi Thalib dianggap salah karena telah menerima tawaran arbitrase dari Amr bin Ash sebagai utusan Muawiyah. Oleh karena itu mereka semua harus dibunuh. Selanjutnya Harun Nasuition (1986: 13) menjelaskan analisis historis kontekstualnya bahwa K aum khawarij pada umumnya terdiri dari orang-orang Arab Badawi (badawah). Mereka hidup di padang pasir yang serba tandus, sehingga mengakibatkan cara hidup dan pemikirannya bersifat sederhana, tetapi keras hati serta berani, dan merdeka. Perubahan agama tidak mengubah sifat-sifat badawiyalnya. Mereka tetap suka kekerasan dan berani mati. Ajaran Islam sebagaimana terdapat dalam al-Qur'an dan hadis mereka artikan secara tekstual dan harus dilaksanakan sepenuhnya. Iman dan paham mereka merupakan iman dan paham orang yang sederhana dalam pemikiran, sempit, dan fanatik. Iman yang tebal, tetapi sempit, dan fanatik ini menjadikan mereka tidak bisa mentoleransi orang yang berbeda paham dengannya. Oleh karena itu, kaum khawarij mudah terpecah 
belah menjadi vaksi-vaksi kecil. Mereka juga mudah melakukan perlawanan-perlawanan secara terus menerus terhadap penguasa yang tidak sejalan dengan keyakinannya.

Aplikasi pendekatan tekstual dan kontekstual terhadap konsep Tauhid Mulkiyah dan Hakimijah merupakan pekerjaan rumah bagi Solahudin selaku penulis buku ini. Solahudin pada awal tulisan memang sudah menampakkan sikap yang berbeda dengan pemikiran orang-orang yang ditulisnya. Namun akan bijak kiranya bila Solahudin juga bersedia menulis pada kesempatan lain tentang pendekatan yang tepat bagi guru PAI setelah mereka membaca konsep TauhidMulkiyahdan Tauhid Hakimiyah. Meminjam ungkapan Komarudin Hidayat (1996:2) di balik sebuah teks sesungguhnya terdapat sekian banyak variabel serta gagasan yang tersembunyi".

\section{Pekerjaan numah khatib dan mubaligh}

Bila bulan Ramadlan tiba, khutbah Jumat di masjid-masjid dan mushala-mushala menyajikan materi yang berbeda dengan bulan sebelumnya. Begitu pula materi untuk pengajian atau kultumnya. Seolah ada instruksi dari atas, sehingga hampir semua masjid dalam khutbah Jumat dan ceramah menyampaikan bahwa jihad ada dua macam, yaitu jihad kecil (JihadalAshghar) dan jihad besar(Jihadal-Akbar). Perang dikategorikan sebagai jihad kecil, sedangkan melawan hawa nafsu adalah jihad besar. Ungkapan tersebut biasa dialamatkan rujukannya pada sabda Nabi Muhammad saw.

Pada zaman Ibnu Taimiyah (1263-1328), hadis tentang jihad kecil dan jihad besar sudah populer di masyarakat. Pemahaman mereka terhadap hadis tersebut sama dengan yang terjadi pada umat Islam di Indonesia. Perang dikategorikan sebagai jihad kecil, sedangkan melawan hawa nafsu adalah jihad besar. Ibnu Taimiyah ketika bermaksud menggelorakan semangat jihad melawan tentara Mongol merasa terhalang oleh pemaknaan hadis tersebut. Oleh karena itu Ibnu Taimiyah menyampaikan kritik bahwa hadis tersebut tidak memiliki sumber yang sahih. Tidak ada seorang ahli hadis dan ulama-ulama yang pemah meriwayatkannya. D engan perkataan lain, hadis tersebut palsu. Pernyataan Ibnu Taimiyah ini pun diikuti oleh begrasi salafy berikutnya.

Kartosuwiryo sebagai Imam DI pertama masih mengakui bahwa perang adalah jihad kecil, sedangkan melawan hawa nafsu adalah jihad besar. Namun, pemahaman kartosuwiryo 
tersebut dikoreksi oleh generasi DI menjalani pelatihan militer di Afganistan. Para alumni Afganistan ini akhirnya mengikuti pendapat ibn Taimiyah yang menyatakan hadis tersebut palsu, sehingga mereka meninggalkannya (Solahudin, 2011: 220-211).

D ari sinilah diketahui bahwa kategorisasi jihad besar dan jihad kecil yang sering disuarakan di masjid-masjid memiliki implikasi serius dalam konteks historis politis umat Islam di dunia. Mengkategorikan perang fisik sebagai jihad kecil dipahami oleh kaum Salafi Jihady sebagai tindakan berpaling dari makna yang sebenamya. Alih-alih dinilai sebagai penghalang terhadap penegakan syari'at Islam. Pemaknaan itu dinilai juga telah mengerdilkan semangat fardlu 'ain terhadap jihad menjadi semangat yang sekadar fardlu kifayah.

Di sisi lain, ada ulama seperti Syeikh Nawawi al-Bantani (1813-1897) yang populer di Indonesia. Syeikh Nawawi adalah ulama Syafi'iyah asal Indonesia yang pernah mendapat kehormatan sebagai guru besar di Mekah (Stenbrink, 1984: 118). Ia menegaskan dalam kitab syarahnya yang berjudul Qam' al-Tugran(t.t.: 10) bahwa Jihad yang bermakna perang dikategorikan sebagai seutama-utama amal pada zaman awal Islam. Selanjutnya ia menjelaskan bahwa Jihad dapat juga bermakna mjahadat al-nafs yaitu berjuang menahan diri dari dorongan hawa nafsu, serta berusaha sekuat tenaga untuk senantiasa melaksanakan perintahperintah Allah dan menjauhi larangan-larangannya. Jihad semacam ini sebagaimana disebut dalam suatu hadis Nabi Muhammad saw., merupakan "jihad akbar" (Jihad besar) dan dianggap lebih utama dari pada jihad dalam arti sempit, memerangi orang-orang kafir (Nawawi, t.t.:10).

Muhammad Chirzin dalam buku Jihad dalamal-Qur'an (2004: 34-37) membahas jihad secara normatif, historis, dan prospektif. Namun ia tidak menyebut "matan hadis" yang diperdebatkan itu. Agus Su'aidi seorang alumnus al-Azhar dalam diskusi dengan penulis (Kamis, 26 April 2012) menyampaikan simpulan yang berbeda dengan Ibnu Taimiyah. Ia menunjuk kitab Zuhdual-Kabir, bab fi Tarki Al-Dunja wa Mukhalafatan-Nafsi al-Hawa, Hadis nomor 384, yang menyebutkan bahwa hadis tersebut diriwayatkan oleh Jabir dalam Baihaqy dengan sanad yang dlaif.

Di sinilah perlu dilakukan koreksi ulang secara akademis terhadap dua pendapat yang berbeda, yaitu antara pendapat Syeikh Nawawi yang sudah biasa disuarakan di masjidmasjid dan pendapat Ibnu Taimiyah yang diikuti oleh kaum Salafy Jihady. Koreksi akademis 
sebaiknya dimulai dari melakukan takhnij hadis secara tepat. Setelah itu dilakukan analisisanalisis tekstual dan kontektual untuk makna yang maslahah bagi umat manusia.

Khatib dan mubaligh memiliki posisi strategis sebagai agen sosialisasi dan diseminasi pemikiran keislaman. Mereka leluasa untuk menyampaikan materi khutbah atau ceramah, sebab tidak terikat dengan struktur birokrasi masjid seperti zaman klasik Islam (Hasan A sari, 1994: 35-36). Keleluasaan mereka itu bertambah seiring dengan arus keterbukaan informasi di zaman sekarang ini. Mubaligh di beberapa daerah juga memiliki tingkat kehormatan tersendiri seiring dengan jumlahnya yang sedikit dan kapasitas ilmunya yang diharapkan oleh masyarakat. Mereka perlu informasi yang bukan hanya benar, tetapi juga aktual. Paradigma berpikir mereka tentang Islam akan berpengruh pada paradigma berpikir umat Islam. Melihat posisi strategis "panggung mubaligh dan khatib", maka hampir semua organisasi Islam berlomba untuk membidik panggung strategis ini. Tak ketinggalan, kelompok usroh dan Jamaah Islamiyah (JI) pernah juga membidik panggung khatib dan mubaligh di tengah masyarakat untuk sarana so sialisasi program dan pelaksanaan tahapan gerakannya (Solahudin, 2011:120,240).

\section{Mengingatkan pemerintah}

Solahudin (2011:77) menyampaikan tesisnya bahwa perang menjadi lahan paling subur bagi pertumbuhan ide-ide jihad dengan semua konsepnya. Termasuk dalam konsep itu adalah irhabijah (terorisme) dan fái (perampokan). jihad adalah ajaran tentang perang suci yang tentu saja habitat utamanya ada di wilayah perang. D alam situasi seperti itu, latar belakang keagamaan menjadi tidak penting. Kelompok tradisionalis maupun modernis bisa berubah dengan segera menjadi kelompok jihadi. Mereka bisa berasal dari kelompok yang berbeda aliran keagamaan, tetapi bertemu dalam satu kepentingan. Ada contoh yang bisa disebutkan. Misalnya, pemikiran Abdullah Azam yang mistikus sufi berbeda memang berbeda dengan Abdullah bin Baz, tetapi mereka bertemu dalam ide jihad untuk Afganistan. Contoh lain, pemikiran Abdullah Sungkar yang purifikatif memang berbeda dengan Ajengan Masduki (pimpinan D I) yang setia pada tarekat, tetapi mereka bertemu dalam kepentingan jihad terhadap rezim O rde Baru Indonesia (Solahudin, 2011: 231). 
Tesis-tesis tersebut merupakan peringatan bagi pemerintah bahwa kekacauan dan keresahan yang terjadi di masyarakat juga bisa menjadi lahan subur tumbuhnya aksi jihad yang menghalalkan terorisme dengan segala bentuknya. Pemerintah perlu sensitivitas yang cerdas ketika di Indonesia ini muncul keresahan seperti yang terjadi pada akhir-akhir. Misalnya, suhu politik yang meningkat seiring dengan pengesahan undang-Undang pemilu (Suara Merdka, Jumat, 20 April 2012: 2). Situasi keamanan yang belum pulih sejak pecah aksi demo menentang kenaikan harga bahan Bakar Minyak (BBM) pada tanggal 26-27 Maret 2012 (SuaraMerdka, Rabu, 28 Maret 2012: 1). Harga BBM yang masih digantung pemerintah sampai sekarang (Suara Meddka, Kamis, 26 A pril 2012). Keresahan masyarakat akibat aksi kekerasan "geng motor" yang marak di berbagai kota (Suara Medkka, Minggu 15 April 2012: 1). Ditambah lagi dengan aksi perampokan yang terjadi di berbagai kota (SuaraMeddka, Selasa, 24 April 2012: 1).

\section{Daftar pustaka}

Nasution, Harun. Tedog Isam AliranAliran, Sgarah Analisa Pebandingan Jakarta: UI Press, 1986.

A sari, Hasan. Menjingkap Zaman Keemasan Idam Kajian atas LembagaLenbaga Pendidikan. Bandung: Mizan, 1994.

Hidayat, Komarudin. Memahami BahasaAgrma: SearahKajianHemmetik.Jakarta: Paramadina, 1996.

Kuntowijoyo. Metoddoj Sgarah Yogyakarta: Tiara wacana, 1994.

Kuntowijoyo. Pengantar Ilmu Sgarah Yogyakarta: Galang press, 2001.

Kuntowijoyo. Međodogj Sejarah Yogyakarta: Tiara wacana, 2003.

Chirzin, Muhammad. Jihad dalamAl-Quran Yogyakarta: Pustaka Pelajar, 2004.

ibn Umar, Muhammad Nawawi. Qam' al-Tugyan 'ala MandzumahSyưabal-Iman Semarang: Toha Putera, t.th.

Solahudin. NII sampai JI SalafyJihadismedi Indonesia Jakarta: Komunitas Bambu, 2011.

Stenbrink, Karel A. Beberapa aspak tentangIdamdi Indonsia abadke19. Jakarta: Bulan Bintang, 1984. 
Ijtihad, Jurnal Wacana Hukum Islam dan Kemanusiaan, Vol. 12, No. 1, Juni 2012: 113-122

\section{Surat Kabar}

Suara Meddka, Rabu, 28 Maret 2012

Suara Merdka, Minggu, 15 April 2012:1.

Suara Medka, Jumat, 20 April 2012.

Suara Merdka Senin, 23 April 2012

Kompas Senin, 23 April 2012).

Suara Merdka, Selasa, 24 April 2012

Suara Merdka, Rabu, 25 April 2012

Suara Merdka, Kamis, 26 April 2012 